\title{
Pengaruh Paclobutrazol terhadap Pertumbuhan dan Perkembangan Tanaman Sanseviera (Sanseviera trifasciata Laurentii)
}

\author{
Effect of Paclobutrazol on Growth and Development of Sanseviera \\ (Sanseviera trifasciata Laurentii) \\ Yafqori Ardigusa ${ }^{1}$ dan Dewi Sukma ${ }^{1 *}$ \\ Diterima 10 Desember 2014/Disetujui 2 Maret 2015
}

\begin{abstract}
The objective of the research was to evaluate the effect of paclobutrazol on Sansevieria growth and development. This research was carried out at Cikabayan green house, IPB from February - July 2010. The study consisted of two factors, i.e., the size of planting material and paclobutrazol concentration. The size of planting material were sucker length $<65 \mathrm{~cm}$ and $\geq 65 \mathrm{~cm}$ and paclobutrazol concentration consisted of 0,62.5, 125, and $250 \mathrm{ppm}$. There were 8 treatments in Completely Randomized Design with there replications. Each experimental unit was one sucker. The result of the experiment showed that size of planting material affected plant height significantly. The highest concentration of paclobutrazol decreased plant height significantly about $19.4 \%$ compared to control. The interaction between size of plant and paclobutrazol only had significant effect on plant height.
\end{abstract}

Keywords : Sanseviera, plant size, Paclobutrazol, growth, development

\begin{abstract}
ABSTRAK
Penelitian ini bertujuan untuk mengetahui pengaruh paclobutrazol terhadap pertumbuhan dan perkembangan Sanseviera. Penelitian ini dilaksanakan pada bulan Februari sampai dengan Juli 2010 di rumah kaca Cikabayan, IPB. Rancangan percobaan menggunakan dua faktor, faktor pertama adalah ukuran bahan tanam terdiri atas bahan tanam (anakan) yang memiliki tinggi $<65 \mathrm{~cm}$ dan $\geq 65 \mathrm{~cm}$ dan konsentrasi paclobutazol, terdiri atas $0,62.5,125$, dan $250 \mathrm{ppm}$. Terdapat 8 kombinasi perlakuan dalam Rancangan Acak Lengkap dengan tiga ulangan. Setiap satuan percobaan ialah satu bahan tanam (anakan). Hasil penelitian menunjukkan bahwa ukuran bahan tanam berpengaruh nyata terhadap tinggi tanaman. Konsentrasi paclobutrazol $250 \mathrm{ppm}$ menghambat pertumbuhan tinggi tanaman sangat nyata sebesar $19.4 \%$ dibanding kontrol. Interaksi antara ukuran bahan tanam dan paclobutrazol hanya berpengaruh nyata pada peubah tinggi tanaman.
\end{abstract}

Kata kunci : Sanseviera, ukuran tanaman, paclobutrazol, pertumbuhan, perkembangan

\section{PENDAHULUAN}

Indonesia memiliki keanekaragaman hayati yang banyak jumlahnya termasuk tanaman hias. Banyak jenis tanaman hias yang mempunyai potensi untuk dikembangkan lebih lanjut. Salah satu yang dapat dikembangkan ialah tanaman Sanseviera atau dikenal dengan nama "Lidah Mertua". Tanaman ini merupakan salah satu komoditi hortikultura yang memiliki daya tarik tersendiri dibandingkan dengan jenis tanaman hias lainnya. Daya tarik tersebut antara lain bentuk daunnya yang bervariasi (bulat lonjong, meruncing, bergelombang), motif dan warna daun, bunga mekar hanya

${ }^{1}$ Departemen Agronomi dan Hortikultura, Fakultas Pertanian, Institut Pertanian Bogor

(Bogor Agricultural University), Jl. Meranti, Kampus IPB Darmaga, Bogor 16680, Indonesia

Telp.\&Faks. 62-251-8629353. *Email korespondensi: dsukma70@yahoo.com 
pada malam hari, dan memiliki manfaat ekologis sebagai penyerap polutan.

Sanseviera tergolong dalam famili Agavaceae yang habitat aslinya adalah daerah tropis yang kering dan mempunyai iklim gurun yang panas. Menurut Purwanto (2006) Sanseviera mengandung bahan aktif pregnane glikosid yang mampu mereduksi polutan menjadi asam organik, gula, dan beberapa senyawa asam amino. Beberapa polutan yang mampu dihancurkan oleh Sanseviera adalah kloroform, benzene, xylene, formaldehid, dan trichloro etilen. Berdasarkan penelitian yang dilakukan oleh Badan Antariksa Amerika Serikat (NASA) menunjukkan bahwa daun Sanseviera mampu menyerap 107 jenis unsur berbahaya. Sanseviera termasuk tanaman hias populer yang banyak dimanfaatkan sebagai penyerap polutan, obat, dan seratnya digunakan dalam industri tekstil. Kendala budidaya Sanseviera yaitu penyediaan bibit dalam jumlah banyak dan waktu singkat sulit dilakukan karena pertumbuhannya yang lambat (Ramadani, 2007).

Salah satu spesies dari Sanseviera yang cukup terkenal adalah Sanseviera trifasciata. Menurut Lingga (2005) Sanseviera trifasciata tersebar luas di berbagai daerah dan banyak diminati masyarakat dan para hobiis. Sanseviera trifasciata memiliki daya adaptasi yang lebih luas dibanding dengan spesies yang lain, tahan terhadap suhu dan pencahayaan yang rendah, mempunyai beberapa subspesies dan kultivar yang menarik untuk tanaman hias, sehingga lebih banyak dibudidayakan dan digunakan untuk pemuliaan tanaman (breeding) dibandingkan dengan spesies lain.

Zat pengatur tumbuh pada tanaman mempunyai peranan dalam pertumbuhan dan perkembangan tanaman. Zat pengatur tumbuh pada tanaman adalah senyawa organik yang bukan hara yang dalam jumlah sedikit dapat mendukung, menghambat, dan dapat mengubah proses fisiologi tumbuhan (Abidin, 1993). Zat pengatur tumbuh yang bersifat menghambat pertumbuhan tanaman disebut sebagai retardan. Retardan dapat menekan pertumbuhan tanaman agar tidak terlalu tinggi dan tidak mudah rebah (Wattimena, 1988). Retardan memiliki kemampuan untuk menghambat sintesis Giberelin (Salisbury dan Ross, 1995).

Paclobutrazol merupakan salah satu jenis retardan yang diharapkan dapat menekan pertumbuhan vegetatif sehingga mengurangi pemanfaatan hasil fotosintesis bagi pertambahan panjang ruas tanaman dan menyebabkan tanaman menjadi lebih pendek, diameter batang menjadi lebih besar dan mencegah kerebahan (Kwon dan Yim, 1986). Selain itu paclobutrazol juga mampu menurunkan sintesis giberelin, mempercepat pembungaan, meningkatkan jumlah bunga, jumlah buah, namun menurunkan fruit-set pada tanaman durian (Sakhidin dan Suparto, 2011) sedangkan dalam kondisi in vitro, Dewi et al. (2014) melaporkan bahwa konsentrasi paclobutrazol 1 $\mathrm{mg} \mathrm{L}^{-1}$ menghambat pertumbuhan tinggi tunas, pertambahan jumlah tunas dan daun jeruk Pamelo cv. Nambangan.

Penelitian ini dilakukan untuk mengetahui pengaruh pemberian paclobutrazol terhadap pertumbuhan dan perkembangan tanaman Sanseviera pada dua ukuran bahan tanam yang berbeda.

\section{BAHAN DAN METODE}

Penelitian ini dilakukan di rumah kaca Cikabayan, Dramaga, Departemen Agronomi dan Hortikultura, Fakultas Pertanian, Institut Pertanian Bogor pada bulan Februari sampai dengan Juli 2010. Ketinggian tempat adalah $240 \mathrm{~m}$ di atas permukaan laut, dengan curah hujan sebesar $300 \mathrm{~mm}$ per bulan.

Bahan yang digunakan adalah media campuran sekam, pupuk kandang, dan tanah dengan perbandingan 1:1:1 (v/v) berdasarkan volume polibag. Tanaman Sanseviera yang digunakan dalam penelitian adalah Sanseviera trifasciata Laurentii. Zat pengatur tumbuh yang digunakan adalah Paclobutrazol dengan konsentrasi berbeda-beda (ppm). Alat-alat yang digunakan meliputi alat pertanian umumnya, sedangkan bahan pertanian meliputi pupuk pestisida dan Rootone-F.

Penelitian menggunakan percobaan faktorial disusun dalam Rancangan Acak Lengkap (RAL) dengan tiga ulangan. Faktor pertama adalah bahan tanaman yang terdiri atas dua ukuran bahan tanam, yaitu tanaman Sanseviera besar (B1) dan tanaman Sanseviera kecil (B2). Kriteria tanaman besar (B1) yaitu tanaman yang memiliki tinggi lebih dari 65 cm, sedangkan kriteria tanaman kecil (B2) yaitu tanaman yang memiliki tinggi kurang dari $65 \mathrm{~cm}$. Jumlah daun pada kedua ukuran 
bahan tanaman lebih kurang 3-4 daun. Faktor kedua adalah konsentrasi paclobutazol yang terdiri atas empat taraf, yaitu kontrol (P0), Paclobutrazol 62.5 ppm (P2), Paclobutrazol 125 ppm (P3), dan Paclobutrazol 250 ppm (P3). Dengan demikian tedapat 8 kombinasi perlakuan. Setiap perlakuan diulang sebanyak tiga ulangan sehingga terdapat 24 satuan percobaan. Setiap satuan percobaan terdiri atas satu tanaman.

Persiapan tanam diawali dengan penyiapan media tanam. Media yang digunakan adalah media campuran sekam, pupuk kandang, dan tanah dengan perbandingan 1:1:1 (v/v) berdasarkan volume polibag. Media dimasukkan ke dalam polibag dengan diameter $50 \mathrm{~cm}$. Bahan tanaman Sanseviera diambil dari kebun tanaman induk yang berumur 8 bulan setelah tanam, dihilangkan tanah yang menempel dengan cara dicuci dengan air kemudian ditanam pada polibag yang telah berisi media baru. Bahan tanaman dibedakan berdasarkan ukurannya seperti disebutkan pada metode percobaan. Pangkal tanaman dicelupkan dalam larutan Rooton-F selama 5 menit sebelum penanaman di polibag. Tanaman diletakkan pada plotnya masing-masing sesuai dengan perlakuan. Pupuk NPK mutiara $(15: 15: 15)$ diberikan pada 0 minggu setelah tanam (MST) sebanyak 10 gram tanaman ${ }^{-1}$. Aplikasi paclobutrazol dilakukan dengan cara disiramkan ke media tanam (soil drenching). Paclobutrazol diaplikasikan pada polibag berisi media tanam dengan volume siram $1000 \mathrm{ml}$ polibag $^{-1}$. Aplikasi ini dilakukan pagi hari sebanyak dua kali yaitu pada 0 MST dan 3 MST setelah transplanting.

Peubah yang diamati meliputi waktu tumbuh tunas, waktu muncul bunga, jumlah anakan, jumlah daun, dan tinggi tanaman. Pengamatan dilakukan sejak tanaman berumur 1 MST untuk masing-masing peubah. Keadaan umum tanaman, hama dan penyakit tanaman diamati secara visual. Data pengamatan diuji dengan sidik ragam. Apabila terdapat perbedaan antar perlakuan dilanjutkan dengan uji lanjutan menggunakan Duncan's Multiple Range Test (DMRT) pada taraf 5\%.

\section{HASIL DAN PEMBAHASAN}

\section{Tinggi Tanaman}

Hasil analisis ragam pengaruh perlakuan terhadap peubah tinggi tanaman menunjukkan bahwa kedua faktor perlakuan (ukuran bahan tanam ataupun paclobutrazol) berpengaruh nyata terhadap tinggi tanaman. Rata-rata tinggi tanaman pada perlakuan disajikan pada Tabel 1.

Tabel 1. Rata-rata tinggi tanaman Sanseviera pada perlakuan Paclobutrazol dan ukuran tanaman

\begin{tabular}{|c|c|c|c|c|c|}
\hline \multirow{2}{*}{ Ukuran Tanaman } & \multicolumn{5}{|c|}{ Perlakuan Paclobutrazol (ppm) } \\
\hline & 0 & 62.5 & 125 & 250 & Rata-rata \\
\hline & \multicolumn{5}{|c|}{ Tinggi Tanaman $(\mathrm{cm})$ pada $1 \mathrm{MST}$} \\
\hline Besar (B1) & 82.3 & 80.7 & 71.8 & 70.4 & $76.3 \mathrm{a}$ \\
\hline Kecil (B2) & 52.0 & 52.3 & 59.7 & 52.3 & $54.1 \mathrm{~b}$ \\
\hline \multirow[t]{2}{*}{ Rata - rata } & $67.2 \mathrm{a}$ & $66.5 \mathrm{a}$ & $65.8 \mathrm{a}$ & $61.4 \mathrm{~b}$ & \\
\hline & \multicolumn{5}{|c|}{ Tinggi Tanaman $(\mathrm{cm})$ pada 5 MST } \\
\hline Besar (B1) & 83.7 & 81.7 & 73.1 & 71.0 & $77.4 \mathrm{a}$ \\
\hline Kecil (B2) & 53.5 & 53.1 & 60.6 & 53.2 & $55.1 \mathrm{~b}$ \\
\hline \multirow[t]{2}{*}{ Rata - rata } & $68.6 \mathrm{a}$ & $67.4 \mathrm{a}$ & $66.8 \mathrm{a}$ & $62.1 \mathrm{~b}$ & \\
\hline & \multicolumn{5}{|c|}{ Tinggi Tanaman $(\mathrm{cm})$ pada 10 MST } \\
\hline Besar (B1) & 87.2 & 83.5 & 74.1 & 71.8 & $79.2 \mathrm{a}$ \\
\hline Kecil (B2) & 55.2 & 54.0 & 61.4 & 53.9 & $56.2 \mathrm{~b}$ \\
\hline \multirow[t]{2}{*}{ Rata - rata } & $71.2 \mathrm{a}$ & $68.8 \mathrm{a}$ & $67.8 \mathrm{a}$ & $62.9 \mathrm{~b}$ & \\
\hline & \multicolumn{5}{|c|}{ Tinggi Tanaman $(\mathrm{cm})$ pada 15 MST } \\
\hline Besar (B1) & 90.0 & 84.9 & 75.1 & 72.5 & $80.6 \mathrm{a}$ \\
\hline Kecil (B2) & 57.4 & 55.1 & 62.1 & 54.4 & $57.2 \mathrm{~b}$ \\
\hline Rata - rata & $73.7 \mathrm{a}$ & $69.7 \mathrm{ab}$ & $68.9 \mathrm{~b}$ & $63.5 \mathrm{c}$ & \\
\hline
\end{tabular}


Berdasarkan Tabel 1 dapat dilihat bahwa tinggi tanaman paling tinggi adalah pada bahan tanam besar (B1) yang memang pada awal tanam lebih tinggi. Nilai rataan tertinggi pada jenis bahan tanam besar (B1) dan jenis bahan tanam kecil (B2) terdapat pada 15 MST sebesar $80.6 \mathrm{~cm}$ dan $57.2 \mathrm{~cm}$. Nilai rataan terendah pada 1 MST sebesar $76.3 \mathrm{~cm}$ (B1) dan $54.1 \mathrm{~cm}$ (B2). Faktor konsentrasi Paclobutrazol menunjukkan pengaruh yang nyata terhadap tinggi tanaman. Konsentrasi Paclobutrazol $250 \mathrm{ppm}$ (P3) berpengaruh nyata pada minggu ke 1 , minggu ke 5 , dan minggu ke 10 MST. Pada minggu ke 15 MST konsentrasi paclobutrazol 125 ppm (P2) dan $250 \mathrm{ppm}$ (P3) memberikan pengaruh nyata terhadap tinggi tanaman. Nilai rataan tertinggi terdapat pada konsentrasi 125 ppm (P2) pada minggu ke 15 MST sebesar $68.9 \mathrm{~cm}$. Nilai rataan terendah terdapat pada minggu ke 1 pada konsentrasi 250 ppm (P3) sebesar 61.4 $\mathrm{cm}$. Interaksi antara faktor jenis bahan tanam dan konsentrasi Paclobutrazol yang menghasilkan tinggi tanaman tertinggi adalah interaksi antara tanaman besar (B1) dengan konsentrasi Paclobutrazol 0 ppm (P0) sebesar $90.0 \mathrm{~cm}$.

Tabel 2. Akumulasi pertambahan tinggi tanaman

\begin{tabular}{llccc}
\hline Ukuran & Paclobutrazol & \multicolumn{3}{c}{ Pertambahan Tinggi dari Tinggi Awal $(\mathrm{cm})$} \\
\cline { 3 - 5 } Tanaman & $(\mathrm{ppm})$ & 5 MST & 10 MST & 15 MST \\
\hline Besar $\left(\mathrm{B}_{1}\right)$ & P0 $(0 \mathrm{ppm})$ & 1.4 & 4.9 & 7.7 \\
& P1 $(62.5 \mathrm{ppm})$ & 1.0 & 2.8 & 4.1 \\
& P2 $(125 \mathrm{ppm})$ & 1.3 & 2.3 & 3.3 \\
& P3 $(250 \mathrm{ppm})$ & 0.5 & 1.4 & 2.1 \\
\hline Kecil $\left(\mathrm{B}_{2}\right)$ & P0 $(0 \mathrm{ppm})$ & 1.5 & 3.2 & 5.4 \\
& P1 $(62.5 \mathrm{ppm})$ & 0.7 & 1.7 & 2.7 \\
& P2 $(125 \mathrm{ppm})$ & 0.9 & 1.8 & 2.4 \\
& P3 $(250 \mathrm{ppm})$ & 0.9 & 1.6 & 2.1 \\
\hline
\end{tabular}

Berdasarkan data pada Tabel 2 terlihat bahwa akumulasi pertambahan tinggi paling besar pada tanaman ukuran besar (B1) tanpa perlakuan paclobutrazol (P0). Makin tinggi konsentrasi paclobutrazol, pertambahan tinggi makin kecil. Menurut Rosmanita (2008) pemberian paclobutrazol menghambat tinggi tanaman anggrek Dendrobium 'Jiad Gold $x$ Booncho Gold'. Paclobutrazol mampu mereduksi pertumbuhan tinggi tanaman Sanseviera ratarata sebesar $19.4 \%$ pada 15 MST jika dibandingkan dengan tanaman kontrol. Menurut Nugroho (2012) Paclobutrazol mampu mereduksi pertumbuhan tinggi tanaman bunga matahari rata-rata sebesar $31.3 \%$ pada setiap minggunya jika dibandingkan dengan tanaman kontrol.

Pertambahan tinggi tanaman paling tinggi pada 5 MST sebesar $1.5 \mathrm{~cm}$ pada bahan tanam kecil (B2) dengan konsentrasi Paclobutrazol $0 \mathrm{ppm}$ (P0). Pertambahan tinggi tanaman paling tinggi pada 10 MST sebesar $4.9 \mathrm{~cm}$ pada bahan tanam besar (B1) dengan konsentrasi 0 ppm (P0). Pertambahan tinggi tanaman paling tinggi pada 15 MST sebesar $7.7 \mathrm{~cm}$ pada bahan tanam besar (B1) dengan konsentrasi $0 \mathrm{ppm}$ (P0). Pertumbuhan tinggi tanaman terendah pada tanaman besar (B1) terdapat pada konsentrasi 250 ppm (P3). Pada bahan tanam kecil (B2), pertumbuhan tinggi tanaman terendah di 5 MST sebesar $0.7 \mathrm{~cm}$ pada konsentrasi 62.5 ppm (P1). Pada 10 dan 15 MST pertumbuhan tinggi terendah terdapat pada konsentrasi 250 ppm (P3) sebesar 1.6 dan $2.1 \mathrm{~cm}$. Santiasrini (2009) mengemukakan bahwa pemberian paclobutrazol dengan konsentrasi yang semakin tinggi (100 sampai $400 \mathrm{ppm}$ ) akan menyebabkan tinggi tanaman Gloksinia semakin rendah.

\section{Jumlah Daun}

Hasil analisis ragam menunjukkan bahwa kedua faktor perlakuan (ukuran bahan tanam ataupun paclobutrazol) tidak berpengaruh nyata terhadap jumlah daun tanaman. Rata-rata jumlah daun disajikan pada Tabel 3. Nilai rata-rata jumlah daun tertinggi terdapat pada tanaman besar (B1) sebesar 5.6 pada 15 MST dan terendah sebesar 3.4 pada tanaman kecil (B2) pada minggu ke 1 MST. Nilai rataan jumlah daun tertinggi terdapat pada konsentrasi $250 \mathrm{ppm}$ (P3) sebesar 5.7 pada minggu ke-15 MST. Nilai rataan jumlah 
daun terendah terdapat pada minggu ke-1 MST sebesar 3.3 pada konsentrasi 125 ppm (P2). Interaksi antara faktor jenis bahan tanam dan konsentrasi Paclobutrazol yang juga tidak berpengaruh nyata terhadap jumlah daun tanaman. Hasil penelitian Rani (2006) dan Nugroho (2012) terhadap tanaman bunga matahari menunjukkan bahwa secara statistik jumlah daun pada tanaman bunga matahari yang diberi perlakuan paclobutrazol dan tanaman kontrol tidak berbeda nyata. Hasil tersebut sesuai dengan apa yang dinyatakan Khrisnamoorthy (1981), bahwa efek fisiologis retardan yaitu menghambat pemanjangan selsel di meristem sub apikal sedangkan pertumbuhan daun terletak pada meristem apikal sehingga jumlah daun tidak terpengaruh oleh pemberian paclobutrazol.

Berdasarkan data pada Tabel 4 terlihat bahwa akumulasi pertambahan jumlah daun paling banyak pada tanaman ukuran besar (B1) dengan konsentrasi 250 ppm (P3). Pertambahan jumlah daun paling tinggi pada 5 MST sebesar 0.7 pada bahan tanam besar (B1) dengan konsentrasi Paclobutrazol 0 ppm (P0), 62.5 ppm (P1) dan bahan tanam kecil (B2) dengan konsentrasi 125 ppm (P2) dan 250 ppm (P3). Pertambahan jumlah daun paling tinggi pada 10 MST sebesar 1.3 pada bahan tanam besar (B1) dengan konsentrasi $62.5 \mathrm{ppm}$ (P1) dan 250 ppm (P3), sedangkan pada bahan tanam kecil (B2) pada konsentrasi 0 ppm (P0).

Tabel 3. Rata-rata jumlah daun Sanseviera pada perlakuan Paclobutrazol

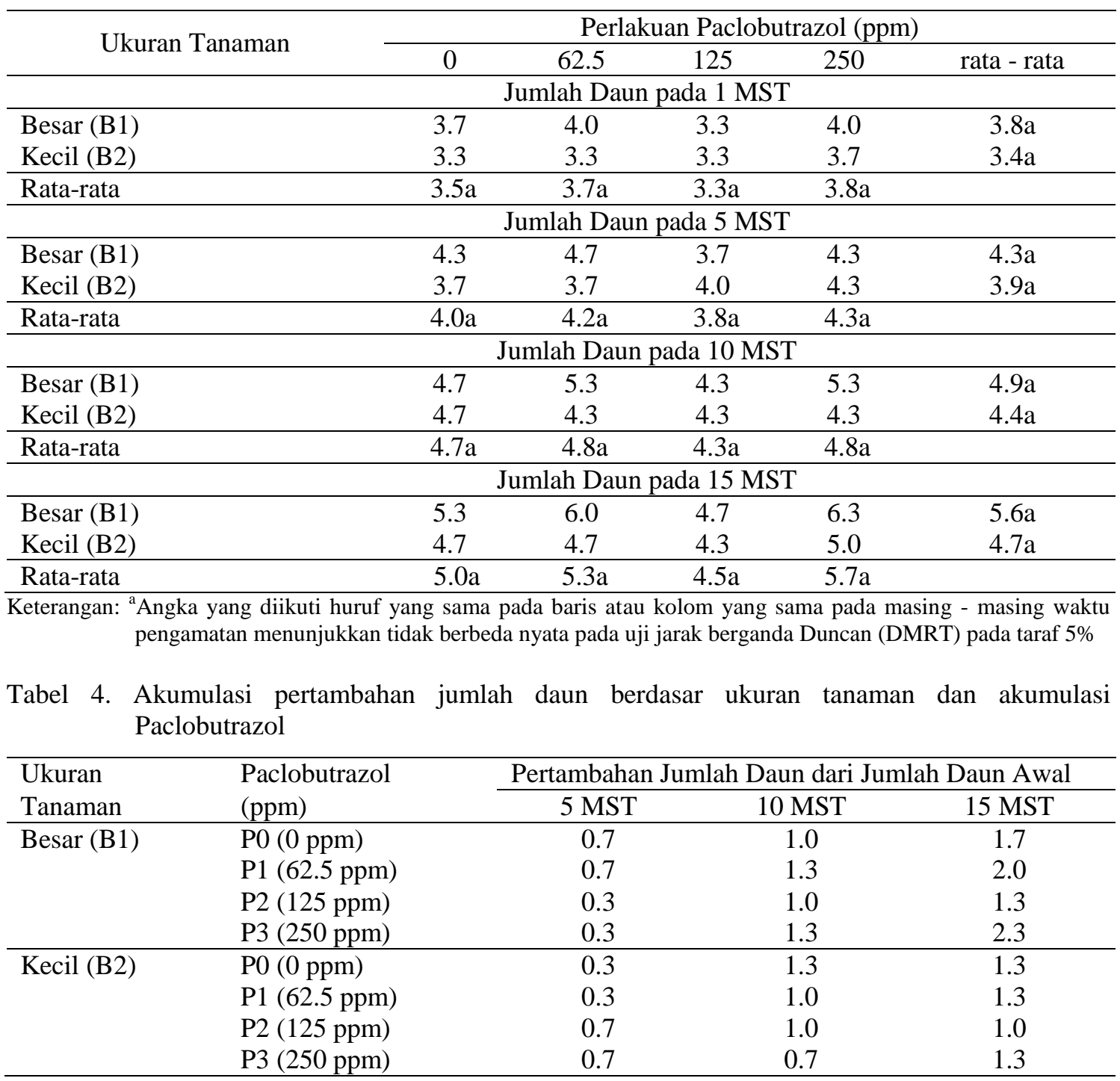


Pertambahan jumlah daun paling tinggi pada 15 MST sebesar 2.3 pada bahan tanam besar (B1) dengan konsentrasi 250 ppm (P3). Pertumbuhan jumlah daun terendah pada tanaman besar (B1) terdapat pada konsentrasi 125 ppm (P2) dan 250 ppm (P3). Bahan tanam kecil (B2), pertumbuhan jumlah daun terendah di 5 MST sebesar 0.3 pada konsentrasi 0 ppm (P0) dan 62.5 ppm (P1). Pada 10 MST pertumbuhan jumlah daun terendah terdapat pada bahan tanam kecil (B2) dengan konsentrasi $250 \mathrm{ppm}$ (P3) sebesar 0.7. Pada 15 MST pertumbuhan jumlah daun terendah terdapat pada konsentrasi 125 ppm (P2) sebesar 1.0.

\section{Jumlah Anakan}

Hasil analisis ragam pengaruh perlakuan terhadap peubah jumlah anakan menunjukkan bahwa kedua faktor perlakuan (ukuran bahan tanam maupun paclobutrazol) tidak berpengaruh nyata terhadap jumlah anakan tanaman. Rata-rata jumlah anakan pada perlakuan disajikan pada Tabel 5 .

Tabel 5 menunjukkan bahwa jumlah rata-rata anakan pada tanaman kecil (B2) sebesar 2.4 dan pada tanaman besar (B1) sebesar 2.2 anakan pada 15 MST yang berarti dalam 15 minggu terbentuk 1-2 anakan. Tabel 6 menunjukkan bahwa paclobutrazol tidak menghambat tumbuhnya anakan baru, namun menekan tinggi tanaman (Tabel 2). Hal ini sesuai dengan hasil penelitan Rosmanita (2008) yang menyatakan bahwa pemberian Paclobutrazol di atas $1 \mathrm{ppm}$ dapat meningkatkan jumlah anakan tanaman anggrek. Wattimena (1988) menambahkan bahwa salah satu efek fisiologis retardan yaitu mendorong terbentuknya tunas.

Akumulasi pertambahan jumlah anakan tercantum pada Tabel 6. Pada 0-5 MST, seluruh tanaman berukuran besar (B1) sudah membentuk anakan, sebaliknya pada tanaman kecil (B2) seluruh tanaman baru semuanya membentuk anakan antara 5-10 MST. Berdasarkan data pada Tabel 7 terlihat bahwa akumulasi pertambahan jumlah anakan pada 5 MST sebesar 2.0 pada bahan tanam besar (B1) dengan konsentrasi Paclobutrazol $250 \mathrm{ppm}$ (P3). Pertambahan jumlah anakan paling tinggi pada 10 MST sebesar 3.3 pada kedua jenis bahan tanam dengan konsentrasi 0 ppm (P0) dan 250 ppm (P3) untuk tanaman besar (B1), konsentrasi 125 ppm (P2) dan 250 ppm (P3) untuk tanaman kecil (B2). Pertambahan jumlah anakan paling tinggi pada 15 MST sebesar 5.7 pada bahan tanam kecil (B2) dengan konsentrasi 125 ppm (P2). Pertumbuhan jumlah anakan terendah pada kedua jenis bahan tanam terdapat pada konsentrasi $62.5 \mathrm{ppm}(\mathrm{P} 1)$.

Tabel 5. Rata -rata jumlah anakan Sanseviera pada perlakuan Paclobutrazol

\begin{tabular}{|c|c|c|c|c|c|}
\hline \multirow{2}{*}{ Ukuran Tanaman } & \multicolumn{5}{|c|}{ Perlakuan Paclobutrazol (ppm) } \\
\hline & 0 & 62.5 & 125 & 250 & rata - rata \\
\hline \multicolumn{6}{|c|}{ Jumlah Anakan pada $1 \mathrm{MST}$} \\
\hline Besar (B1) & 1.0 & 1.0 & 1.0 & 1.0 & $1.0 \mathrm{a}$ \\
\hline Kecil (B2) & 1.0 & 1.0 & 1.0 & 1.0 & $1.0 \mathrm{a}$ \\
\hline Rata - rata & $1.0 \mathrm{a}$ & $1.0 \mathrm{a}$ & $1.0 \mathrm{a}$ & $1.0 \mathrm{a}$ & \\
\hline \multicolumn{6}{|c|}{ Jumlah Anakan pada 5 MST } \\
\hline Besar (B1) & 1.5 & 1.5 & 1.4 & 1.7 & $1.5 \mathrm{a}$ \\
\hline Kecil (B2) & 1.1 & 1.1 & 1.6 & 1.4 & $1.3 \mathrm{a}$ \\
\hline Rata - rata & $1.3 \mathrm{a}$ & $1.3 \mathrm{a}$ & $1.5 \mathrm{a}$ & $1.6 \mathrm{a}$ & \\
\hline \multicolumn{6}{|c|}{ Jumlah Anakan pada 10 MST } \\
\hline Besar (B1) & 2.0 & 1.7 & 1.9 & 2.1 & $1.9 \mathrm{a}$ \\
\hline Kecil (B2) & 2.0 & 1.9 & 2.1 & 2.1 & $2.0 \mathrm{a}$ \\
\hline Rata - rata & $2.0 \mathrm{a}$ & $1.8 \mathrm{a}$ & $2.0 \mathrm{a}$ & $2.1 \mathrm{a}$ & \\
\hline \multicolumn{6}{|c|}{ Jumlah Anakan pada 15 MST } \\
\hline Besar (B1) & 2.2 & 1.9 & 2.1 & 2.5 & $2.2 \mathrm{a}$ \\
\hline Kecil (B2) & 2.4 & 2.1 & 2.6 & 2.3 & $2.4 \mathrm{a}$ \\
\hline Rata - rata & $2.3 \mathrm{a}$ & $2.0 \mathrm{a}$ & $2.3 \mathrm{a}$ & $2.4 \mathrm{a}$ & \\
\hline
\end{tabular}


Tabel 6. Akumulasi pertambahan jumlah anakan

\begin{tabular}{llccc}
\hline Ukuran & Paclobutrazol & \multicolumn{3}{c}{ Pertambahan Jumlah Anakan dari Jumlah Awal } \\
\cline { 2 - 5 } Tanaman & $(\mathrm{ppm})$ & 5 MST & 10 MST & 15 MST \\
\hline Besar (B1) & P0 $(0 \mathrm{ppm})$ & 1.3 & 3.3 & 4.3 \\
& P1 (62.5 ppm) & 1.3 & 2.0 & 3.0 \\
& P2 (125 ppm) & 1.0 & 2.7 & 3.7 \\
& P3 (250 ppm) & 2.0 & 3.3 & 5.3 \\
\hline Kecil (B2) & P0 (0 ppm) & 0.3 & 3.0 & 5.0 \\
& P1 (62.5 ppm) & 0.3 & 2.7 & 3.7 \\
& P2 (125 ppm) & 1.7 & 3.3 & 5.7 \\
& P3 (250 ppm) & 1.0 & 3.3 & 4.3 \\
\hline
\end{tabular}

Tabel 7. Jumlah dan persentase waktu tanaman membentuk anakan baru

\begin{tabular}{|c|c|c|c|c|c|c|c|}
\hline \multirow[t]{2}{*}{ Perlakuan } & \multicolumn{5}{|c|}{$\begin{array}{c}\text { Persentase Waktu Tanaman Membentuk Anakan } \\
\text { Baru (MST) }\end{array}$} & \multirow{2}{*}{$\begin{array}{c}\text { Jumlah Total } \\
\text { Anakan pada } \\
15 \text { MST }\end{array}$} & \multirow{2}{*}{$\begin{array}{c}\text { Rata-rata } \\
\text { Jumlah } \\
\text { Anakan }\end{array}$} \\
\hline & 3 & 6 & 9 & 12 & 15 & & \\
\hline \multirow{3}{*}{ B1P0 } & $1 / 3$ & $2 / 3$ & $3 / 3$ & $3 / 3$ & $3 / 3$ & & \\
\hline & $(33.3 \%)$ & $(66.7 \%)$ & $(100 \%)$ & $(100 \%)$ & $(100 \%)$ & 13 & 4.3 \\
\hline & $1 / 3$ & $2 / 3$ & $3 / 3$ & $3 / 3$ & $3 / 3$ & & \\
\hline \multirow[t]{2}{*}{ B1P1 } & $(33.3 \%)$ & $(66.7 \%)$ & $(100 \%)$ & $(100 \%)$ & $(100 \%)$ & 9 & 3.0 \\
\hline & $1 / 3$ & $3 / 3$ & $3 / 3$ & $3 / 3$ & $3 / 3$ & & \\
\hline \multirow[t]{2}{*}{$\mathrm{B} 1 \mathrm{P} 2$} & $(33.3 \%)$ & $(100 \%)$ & $(100 \%)$ & $(100 \%)$ & $(100 \%)$ & 11 & 3.7 \\
\hline & $2 / 3$ & $3 / 3$ & $3 / 3$ & $3 / 3$ & $3 / 3$ & & \\
\hline \multirow[t]{2}{*}{$\mathrm{B} 1 \mathrm{P} 3$} & $(66.7 \%)$ & $(100 \%)$ & $(100 \%)$ & $(100 \%)$ & $(100 \%)$ & 16 & 5.3 \\
\hline & $0 / 3$ & $2 / 3$ & $3 / 3$ & $3 / 3$ & $3 / 3$ & & \\
\hline \multirow[t]{2}{*}{$\mathrm{B} 2 \mathrm{P} 0$} & $(0 \%)$ & $(66.7 \%)$ & $(100 \%)$ & $(100 \%)$ & $(100 \%)$ & 15 & 5.0 \\
\hline & $1 / 3$ & $3 / 3$ & $3 / 3$ & $3 / 3$ & $3 / 3$ & & \\
\hline \multirow[t]{2}{*}{$\mathrm{B} 2 \mathrm{P} 1$} & $(33.3 \%)$ & $(100 \%)$ & $(100 \%)$ & $(100 \%)$ & $(100 \%)$ & 11 & 3.7 \\
\hline & $1 / 3$ & $3 / 3$ & $3 / 3$ & $3 / 3$ & $3 / 3$ & & \\
\hline \multirow{2}{*}{$\mathrm{B} 2 \mathrm{P} 2$} & $(33.3 \%)$ & $(100 \%)$ & $(100 \%)$ & $(100 \%)$ & $(100 \%)$ & 17 & 5.7 \\
\hline & $0 / 3$ & $3 / 3$ & $3 / 3$ & $3 / 3$ & $3 / 3$ & & \\
\hline $\mathrm{B} 2 \mathrm{P} 3$ & $(0 \%)$ & $(100 \%)$ & $(100 \%)$ & $(100 \%)$ & $(100 \%)$ & 13 & 4.3 \\
\hline
\end{tabular}

Keterangan: ${ }^{\mathrm{a}} \mathrm{B} 1 \mathrm{P} 0=$ Tanaman Besar, Tanpa Paclobutrazol, B1P1 = Tanaman Besar, Paclobutrazol 62.5 ppm, B1P2 = Tanaman Besar, Paclobutrazol 125 ppm, B1P3 = Tanaman Besar, Paclobutrazol 250 ppm, B2P0 = Tanaman Kecil, Tanpa Paclobutrazol, B2P1 = Tanaman Kecil, Paclobutrazol 62.5 ppm, B2P2 = Tanaman Kecil, Paclobutrazol 125 ppm, B2P3 = Tanaman Kecil, Paclobutrazol 250 ppm.

Berdasarkan Tabel 7 terlihat bahwa kombinasi perlakuan yang menghasilkan anakan tercepat dengan persentase terbesar adalah B1P3 (tanaman ukuran besar dengan perlakuan paclobutrazol $250 \mathrm{ppm}$ ), sedangkan perlakuan yang menghasilkan anakan paling lambat dengan persentase terkecil adalah B2P0 (tanaman ukuran kecil tanpa perlakuan paclobutrazol) dan B2P3 (tanaman ukuran kecil dengan perlakuan paclobutrazol 250 ppm). Kombinasi perlakuan B1P2 (tanaman ukuran besar dengan perlakuan paclobutrazol 125 ppm), B1P3 (tanaman ukuran besar dengan perlakuan paclobutrazol $250 \mathrm{ppm}$ ), B2P1 (tanaman ukuran kecil dengan perlakuan paclobutrazol $62.5 \mathrm{ppm}$ ), B2P2 (tanaman ukuran kecil dengan perlakuan paclobutrazol 125 ppm), B2P3 (tanaman ukuran kecil dengan perlakuan paclobutrazol $250 \mathrm{ppm}$ ) merupakan yang tercepat dalam keseragaman waktu dan jumlah total muncul anakan pada 6 MST. Seluruh kombinasi perlakuan mencapai keseragaman jumlah total dan waktu muncul anakan pada 9 MST. Jumlah total dan rata-rata jumlah anakan tertinggi terdapat pada kombinasi B2P2 (tanaman ukuran kecil dengan perlakuan paclobutrazol $125 \mathrm{ppm}$ ), sedangkan kombinasi yang menghasilkan jumlah total dan rata-rata jumlah anakan terendah terdapat pada kombinasi B1P1 (tanaman ukuran besar dengan perlakuan paclobutrazol $62.5 \mathrm{ppm}$ ). 
Tabel 8. Jumlah dan persentase waktu tanaman berbunga

\begin{tabular}{|c|c|c|c|c|c|c|c|}
\hline \multirow{2}{*}{ Perlakuan } & \multicolumn{5}{|c|}{ Persentase Waktu Tanaman Berbunga (MST) } & \multirow{2}{*}{$\begin{array}{c}\text { Jumlah Bunga } \\
\text { Total pada } 15 \\
\text { MST }\end{array}$} & \multirow{2}{*}{$\begin{array}{c}\text { Rata-rata } \\
\text { Jumlah } \\
\text { Bunga }\end{array}$} \\
\hline & 3 & 6 & 9 & 12 & 15 & & \\
\hline \multirow{3}{*}{ B1P0 } & $0 / 3$ & $0 / 3$ & $2 / 3$ & $3 / 3$ & $3 / 3$ & & \\
\hline & $(0 \%)$ & $(0 \%)$ & $(66.7 \%)$ & $(100 \%)$ & $(100 \%)$ & 3 & 1.0 \\
\hline & $0 / 3$ & $0 / 3$ & $2 / 3$ & $3 / 3$ & $3 / 3$ & & \\
\hline \multirow[t]{2}{*}{ B1P1 } & $(0 \%)$ & $(0 \%)$ & $(66.7 \%)$ & $(100 \%)$ & $(100 \%)$ & 3 & 1.0 \\
\hline & $3 / 3$ & $3 / 3$ & $3 / 3$ & $3 / 3$ & $3 / 3$ & & \\
\hline \multirow[t]{2}{*}{$\mathrm{B} 1 \mathrm{P} 2$} & $(100 \%)$ & $(100 \%)$ & $(100 \%)$ & $(100 \%)$ & $(100 \%)$ & 6 & 2.0 \\
\hline & $1 / 3$ & $1 / 3$ & $2 / 3$ & $3 / 3$ & $3 / 3$ & & \\
\hline \multirow[t]{2}{*}{ B1P3 } & $(33.3 \%)$ & $(33.3 \%)$ & $(66.7 \%)$ & $(100 \%)$ & $(100 \%)$ & 4 & 1.3 \\
\hline & $0 / 3$ & $0 / 3$ & $3 / 3$ & $3 / 3$ & $3 / 3$ & & \\
\hline \multirow[t]{2}{*}{$\mathrm{B} 2 \mathrm{P} 0$} & $(0 \%)$ & $(0 \%)$ & $(100 \%)$ & $(100 \%)$ & $(100 \%)$ & 3 & 1.0 \\
\hline & $0 / 3$ & $0 / 3$ & $2 / 3$ & $3 / 3$ & $3 / 3$ & & \\
\hline \multirow[t]{2}{*}{$\mathrm{B} 2 \mathrm{P} 1$} & $(0 \%)$ & $(0 \%)$ & $(66.7 \%)$ & $(100 \%)$ & $(100 \%)$ & 3 & 1.0 \\
\hline & $2 / 3$ & $2 / 3$ & $3 / 3$ & $3 / 3$ & $3 / 3$ & & \\
\hline \multirow[t]{2}{*}{$\mathrm{B} 2 \mathrm{P} 2$} & $(66.7 \%)$ & $(66.7 \%)$ & $(100 \%)$ & $(100 \%)$ & $(100 \%)$ & 5 & 1.7 \\
\hline & $2 / 3$ & $2 / 3$ & $3 / 3$ & $3 / 3$ & $3 / 3$ & & \\
\hline B2P3 & $(66.7 \%)$ & $(66.7 \%)$ & $(100 \%)$ & $(100 \%)$ & $(100 \%)$ & 5 & 1.7 \\
\hline
\end{tabular}

Keterangan: ${ }^{a} \mathrm{~B} 1 \mathrm{P} 0=$ Tanaman besar, Tanpa paclobutrazol, B1P1 = Tanaman besar, Paclobutrazol 62.5 ppm, B1P2 = Tanaman besar, Paclobutrazol 125 ppm, B1P3 = Tanaman besar, Paclo 250 ppm, B2P0 = Tanaman kecil, Tanpa paclo, B2P1 = Tanaman kecil, Paclo 62.5 ppm, B2P2 = Tanaman kecil, Paclo 125 ppm, B2P3 = Tanaman kecil, Paclo 250 ppm.

\section{Waktu Muncul Bunga}

Pada Tabel 8 terlihat bahwa kombinasi perlakuan yang menghasilkan bunga tercepat dengan persentase terbesar adalah $\mathrm{B} 1 \mathrm{P} 2$ (tanaman ukuran besar dengan perlakuan paclobutrazol $125 \mathrm{ppm}$ ), sedangkan perlakuan yang menghasilkan bunga paling lambat dengan persentase terkecil adalah B1P0 (tanaman ukuran besar dengan perlakuan tanpa paclobutrazol), B1P1 (tanaman ukuran besar dengan perlakuan paclobutrazol $62.5 \mathrm{ppm}$ ), B2P0 (tanaman ukuran kecil dengan perlakuan tanpa paclobutrazol), dan B2P1 (tanaman ukuran kecil dengan perlakuan paclobutrazol $62.5 \mathrm{ppm})$.

Penghambatan waktu muncul bunga disebabkan oleh konsentrasi paclobutrazol yang digunakan belum sesuai karena setiap tanaman mempunyai sensitifitas yang berbedabeda terhadap zat penghambat tumbuh (Rosmanita, 2008). Menhennet dalam Nugroho (2012) menyatakan bahwa perlakuan zat pengatur tumbuh pada waktu dan konsentrasi yang tidak tepat akan menunda pembungaan hal ini disebabkan pembentukan beberapa zat yang diperlukan tanaman untuk pembentukan primordia bunga terhambat. Krishnamoorthy (1981) menambahkan bahwa retardan merupakan senyawa kimia yang mempunyai efek fisiologis menghambat pemanjangan sel di meristem sub apikal, sedangkan jumlah daun, bunga dan buah tidak dipengaruhinya.

Seluruh kombinasi perlakuan mencapai keseragaman berbunga pada 12 MST. Jumlah total dan rata-rata jumlah bunga tertinggi terdapat pada kombinasi B1P2 (tanaman ukuran besar dengan perlakuan paclobutrazol 125 ppm), sedangkan kombinasi yang menghasilkan jumlah total dan rata-rata jumlah bunga terendah terdapat pada kombinasi B1P0, B1P1, B2P0, dan B2P1.

\section{KESIMPULAN}

Konsentrasi Paclobutrazol menghambat pertumbuhan tinggi tanaman, tetapi tidak berpengaruh nyata terhadap jumlah daun dan jumlah anakan. Jenis bahan tanam berpengaruh nyata terhadap tinggi tanaman, tetapi tidak berpengaruh terhadap jumlah daun dan jumlah anakan. Interaksi antara konsentrasi Paclobutrazol dan jenis bahan tanam berpengaruh nyata terhadap peubah tinggi tanaman, tetapi tidak berpengaruh nyata terhadap peubah jumlah daun dan jumlah anakan. Tanaman Sanseviera trifasciata dengan ukuran 
$\geq 65 \mathrm{~cm}$ lebih cepat menghasilkan anakan pada konsentrasi Paclobutrazol $250 \mathrm{ppm}$. Sanseviera dengan ukuran tersebut juga lebih cepat menghasilkan bunga pada konsentrasi Paclobutrazol 125 ppm.

\section{DAFTAR PUSTAKA}

Abidin, Z. 1993. Dasar-dasar Pengetahuan tentang Zat Pengatur Tumbuh. Angkasa, Bandung. 84 hal.

Dewi, I.S., G.S. Jawak, B.S. Purwoko, M. Sabda. 2014. Respon pertumbuhan kultur in vitro jeruk besar (Citrus maxima (Burm.) Merr.) cv. Nambangan terhadap osmotikum dan ratardan. J. Hort Indonesia. 5(1): 21-28.

Khrisnamoorthy, H.N. 1981. Plant Growth Substances Including Applications in Agriculture. McGaw-Hill Publ. New Delhi. 214p.

Kwon, Y.M., Yim. 1986. Paclobutrazol in Rice. In Plant Growth Yama I. ASPAC, Taipe.

Lingga, L. 2005. Panduan Praktis Budidaya Sanseviera PT. Gramedia Pustaka Utama, Jakarta.

Nugroho, P.T. 2012. Pengaruh Paclobutrazol dan komposisi larutan pulsing terhadap kualitas pasca panen bunga matahari (Helianthus annuus L.) sebagai bunga potong. Skripsi. Departemen Agronomi dan Hortikultura. Fakultas Pertanian. Institut Pertanian Bogor. Bogor.

Purwanto, A.W. 2006. Sanseviera Flora Cantik Penyerap Racun. Kanisius. Yogyakarta.
Ramadani,S. 2007. Respon Pertumbuhan Sansivieria Terhadap Konsentrasi IBA dan Sumber Bahan Tanam. Universitas Lampung.

Rani, I. 2006. Pengendalian pertumbuhan tanaman bunga matahari (Helianthus annuиs L.) dengan aplikasi paclobutrazol. Skripsi. Program Studi Hortikultura, Fakultas Pertanian, Institut Pertanian Bogor. Bogor.

Rosmanita, B. 2008. Pengaruh Paclobutrazol dan pupuk daun terhadap pertumbuhan dan perkembangan anggrek Dendrobium 'Jiad Gold x Booncho Gold'. Skripsi. Program Studi Hortikultura. Fakultas Petanian. Institut Pertanian Bogor. Bogor.

Sakhidin, S.R. Suparto. 2011. Kandungan giberelin, kinetin, dan asam absisat pada tanaman durian yang diberi paclobutrazol dan etepon. J. Hort Indoneia. 2(1): 21-26.

Salisbury, F.B., C.W. Ross. 1995. Fisiologi Tumbuhan. Jilid 3 (diterjemahkan oleh Dian, L., Lukman, Sumaryono) ITB, Bandung.

Santiasrini, R. 2009. Pengaruh paclobutrazol terhadap pertumbuhan dan pembungaan gloksinia (Sinningia speciosa Pink). Skripsi. Program Studi Hortikultura. Fakultas Petanian. Institut Pertanian Bogor. Bogor.

Wattimena, G.A. 1988. Zat Pengatur Tumbuh Tanaman. Lembaga Sumber Daya Informasi IPB. Bogor. 